\title{
Sixth International Botanical Congress
}

\begin{abstract}
AMSTERDAN
A

BOUT nine hundred members, including delegates from more than fifty countries, attended the sixth International Botanical Congress at Amsterdam in the first week in September. The muchregretted death of Prof. F. A. F. C. Went had, a few weeks previously, deprived the Congress of its president. His place was taken by Prof. J. C. Schoute, who, in welcoming the members at the opening meeting, referred to the great loss to botany and to their regret that the directing hand had been unable to carry the work to completion.

The papers in the various sections were given by invitation of the executive committee, and were grouped under headings. A great variety of subjects were included, of special and general interest, the latter often affording combined meetings with other sections. Thus the evolution of angiosperms interested palæobotany and taxonomy, flower morphology attracted taxonomists as well as morphologists, and "Taxonomy and Genetics" had an obvious dual interest. Joint discussions were indicated between cytology and genetics, between each of these and mycology, between agronomy and phytopathology or physiology and so on. The programme, a marvel of condensation in three languages, informed members as to subject, date and place of meeting, and a volume of abstracts of the papers provided a useful handbook. Members interested in special studies found opportunity for informal meeting and discussion.

The Nomenclature Section of Taxonomy, under the presidency of Dr. Merrill, worked through a series of proposals, the main purpose of which was to clarify points, where desirable, in the recent edition of the "Rules of Nomenclature". Certain additions suggested by the palæobotanists to meet difficulties, arising especially from the fragmentary character of the material, were accepted.

An admirable "History of Botany in the Netherlands" had been prepared by the senior secretary, Dr. M. J. Sirks, and a pamphlet by Prof. Leeuw described in detail the Netherlands as an environment for plant life.
\end{abstract}

\section{MeEting}

Linnæus was a student at Leyden, and his early botanical work was done in Holland. The bicentenary of the publication of his "Systema Naturæ" (Leyden, 1735) was commemorated by an appropriate exhibit of Linneana at Amsterdam during the Congress.

Days reserved for excursions gave opportunity for visiting botanical laboratories and gardens, as at Utrecht, Leyden, Baarn. Special care was taken by those in charge to make the visits instructive and interesting. The botanical garden at Leyden is one of the oldest in Europe. Founded in 1587, it was laid out under the supervision of Clusius in 1594, and members were shown a replica of his garden recently prepared from an original plan and inventory. More than 1,000 species and varieties were represented, and it showed a character, novel for the time, of a botanical, not merely a medical, garden. At Baarn, the extensive collections of pure cultures of fungi, amounting to 5,000 units, under the care of Dr. Joh. Westerdyk, were visited and at Lisse the admirably equipped bulb research laboratories.

A drive along the old Zuyder Zee and on the dam which now holds back the North Sea was an object lesson in the essentially Dutch art of converting sea. flooded areas into cultivable polderland. Various stages in conversion were seen, culminating in a polder bearing crops and two new villages which five years ago was open sea.

Pleasant social functions were evening receptions by the Netherlands Botanical Society, and, at the Rijksmuseum, by the Netherlands Government; the latter gave opportunity of inspecting the famous picture galleries.

At the final plenary meeting, an invitation from Sweden to hold the meeting in 1940 at Stockholm was accepted. An invitation to meet in South Africa had been withdrawn.

The executive committee is to be congratulated on its successful organisation; special mention is due to the senior secretary, Dr. M. J. Sirks.

A. B. Rendie.

\section{Twelfth International Congress of Zoology}

\section{Lisbon MEeTing}

$\mathrm{I}^{\mathrm{N}}$ $\mathrm{N}$ view of the restrictions on foreign travel imposed in several European countries it was expected that the number of members attending the Congress of Zoology which was held at Lisbon on September 15-21 might fall short of that reached at some previous meetings of the Congress. In the event, however, the number proved to be little, if at all, less than that of the last meeting at Padua in 1930. Under the presidency of Prof. Arthur Ricardo Jorge, some five hundred members took part, and the programme showed about two hundred separate com. munications to be read either before the full Congress or at the sessions of the twelve sections into which it divided.
At the opening meeting, presided over by the President of the Portuguese Republic, the Minister of Public Instruction welcomed the Congress and delivered an address on the place of biology in education, in which he advocated instruction in the principles of biology as a necessary preparation for the teaching of ethics, civics and even politics.

It is not possible here to enumerate even the more important of the communications made to the Congress, but one or two may be mentioned which, for different reasons, happened to interest members of the British delegation. Prof. R. Anthony (Paris) gave an address on the evolution of the molar teeth in mammals, in the course of which he criticised 
once again the much criticised 'tritubercular theory'. In this, he was supported by Mr. Hinton, of the Zoological Department of the British Museum. Prof. R. Goldschmidt (Berlin) gave an account of the progress of his long-continued researches on the genetics of local races of the gipsy moth, and came to the conclusion that local races do not represent a stage in the evolution of species. Prof. Przibram (Vienna) demonstrated living specimens of a stick insect in which transplanted legs were voluntarily movable, although sections of similar specimens failed to reveal any connexion with the central nervous system.

Dr. Calman directed attention to the centenary of Darwin's visit to the Galapagos Islands and to the action of the Government of Ecuador in declaring certain of the islands a Nature reserve. The Congress adopted a resolution expressing its appreciation of the step taken by the Ecuadorian Government and offering its co-operation in any further action that might be necessary to preserve from extinction the very interesting fauna of the islands.

Probably no section of the Congress worked harder than the members of the International Com. mission on Zoological Nomenclature who sat (mostly in their shirt-sleeves !) for several hours each day under the chairmanship of Dr. Jordan of Tring, striving to disentangle the complexities of the problems submitted to them. For the first time in many Congresses, they met without their indefatigable secretary, Dr. C. W. Stiles, of Washington, who was prevented by illness from travelling to Lisbon. The result of their labours was the addition to the official list of nomina conservanda of a considerable number of generic names, mostly of insects, that were threatened with displacement or transference by a strict application of the rule of priority.

Unfortunately, some of the rooms where the meetings were held proved defective in their acoustic qualities. In particular, the lofty hall used for the plenary sessions, being lined with polished marble, provided an excellent demonstration of the reflection of sound. Since each speaker used a language which was foreign to some eighty per cent of his audience, effective discussion was impossible except where an abstract of the paper had been supplied beforehand. It is to be hoped that at future Congresses an attempt will be made to print abstracts of all papers and to distribute them well in advance of the opening day, and perhaps even to supply the full text of the more important addresses.

Finally, mention should be made of the lavish hospitality shown to the Congress by the Portuguese Government, the Municipality and the University of Lisbon, and the Municipality of Sintra, as well as by the Portuguese zoologists themselves. Many northern zoologists, making acquaintance for the first time with the brilliant sunshine, the blue sea, and the subtropical vegetation of Portugal, will not soon forget the friendliness of their Portuguese colleagues.

\section{International Meteorological Conference}

\section{WARSAW MEeting}

$\mathrm{T}$ HE International Meteorological Conference is an assembly, which meets every six years, of the directors of meteorological services in all parts of the world. A meeting was due in 1935, and by invitation of Dr. J. Lugeon, director of the National Meteorological Service of Poland, it was held in the Palais Stasjic, Warsaw, on September 6-13 under the presidency of Prof. E. van Everdingen. The conference was formally opened by the President of the Republic of Poland on September 6, and an address of welcome was delivered by the Minister of Communications. Only directors can be members of the full conference, but much of the detailed work of organisation is carried out by commissions nominated for special subjects, and each commission is composed of those meteorologists who are most expert in the work of the commission. Meetings of nearly all the commissions were held either in Warsaw before and during the main conference, or in Danzig during the preceding week.

The work of the conference and commissions covers a very wide field--synoptic meteorology, investigation of the upper air, climatology, agricultural meteorology, maritime meteorology, terrestrial magnetism, bibliography, etc., with many ramifications of detail. Synoptic meteorology, including the taking of observations at agreed hours, their broadcasting in code, reception and plotting on charts, has required the building up of an international organisation of great complexity, which is of vital importance not only for daily weather forecasting, but also for avia- tion. The extension of regular long-distance flying, in particular, has had the result that pilots pass from one country to another, and need to consult a variety of different weather charts, not only for the general isobars and winds, but also for details such as the form and height of clouds, or the presence of fog, thunderstorms, etc. To avoid confusion, the observations must be made and coded in a uniform manner -for which purpose detailed instructions in the use of the codes have been drawn up for international use. It is equally important, however, that the weather reports should be entered on the weather charts of different countries, according to a general plan, so that the pilot knows at once exactly where to look for the particular information which he requires. This 'station model', as it is termed, has been the subject of very careful consideration at Warsaw by the Commission for Synoptic Weather Information, and a great measure of agreement has been arrived at as to the form which it should take.

Another subject studied by this commission also concerns the international language of meteorology, namely the symbols used to represent various meteorological phenomena. At Warsaw, several new symbols, especially one for drizzle, were added to this international language. Finally, among a number of minor improvements in the codes for weather reports must be signalised the beginning of the arrangements for the inter-continental exchange of weather information by wireless, with the view of preparing within a few hours daily weather 